\title{
A CONSISTENT AYRTON-PERRY APPROACH FOR THE FLEXURAL-TORSIONAL BUCKLING RESISTANCE EVALUATION OF STEEL I-SECTION MEMBERS
}

\author{
Marian GIŻEJOWSKI ${ }^{1}$, Zbigniew STACHURA \\ Warsaw University of Technology, Faculty of Civil Engineering, \\ Institute of Building Engineering, Poland
}

\begin{abstract}
Steel I-section members subjected to compression a monoaxial bending about the major axis are dealt with in this paper. The current Eurocode's design procedure of such members is based on a set of two interpolation equations. In this paper a simple and yet consistent Ayrton-Perry methodology is presented that for beam-columns yields the Ayrton-Perry design strategy similar to that utilized in the steel Eurocodes for design of beams and columns but not used so far for the beam-column design. The results from developed design criterion are compared with those of Method 1 of Eurocode 3 and the Ayrton-Perry formulation of a different format that has been recently published.

Keywords: steel I-section, beam-column, buckling resistance, flexural-torsional buckling, generalized Ayrton-Perry formulation, Eurocode's design philosophy
\end{abstract}

\section{INTRODUCTION}

Interaction equations proposed in [1] for design of steel I-section members cover a wide range of cases, i.e. both unrestrained elements for which the flexuraltorsional buckling mode becomes a dominating failure factor and elements restrained laterally and torsionally in discrete point along the element length for

\footnotetext{
${ }^{1}$ Corresponding author: Warsaw University of Technology, Faculty of Civil Engineering, Institute of Building Engineering, al. Armii Ludowej 16, 00-637 Warszawa, Poland, e-mail: m.gizejowski@il.pw.edu.pl, tel. +48 228258421
} 
which the flexural in-plane buckling mode becomes a more susceptible one. For the background information one has to refer to [10].

Besides the design criteria based on interaction equations, Eurocode 3 [1] introduces the so-called general method for the evaluation of out-of-plane buckling resistance (FTB resistance) of beam-columns the validation of which is presented in [9]. Different Eurocode's procedures that might be used for design of steel frames are summarized in the papers presented at ICMS 2016 [2, 4]. The design procedures are based on the weakest element approach or on tracing the structure nonlinear equilibrium path. The resistance evaluation based on the latter procedure yields from an attainment of either the section resistance in the most stressed member during the stress resultants redistribution process or the structure limit point on the equilibrium path.

Recently, an international research effort has been made into the resistance assessment of steel beam-columns being based on the generalized Ayrton-Perry formulation $[8,12]$. The proposals presented there are dedicated rather to unrestrained beam-columns than to members with discrete in-span lateral and torsional restraints.

Authors focused in this paper on the development of generalized Ayrton-Perry formulation that is an alternative one to that presented in [12]. This alternative approach allows covering not only unrestrained beam-columns but also the elements that have in-span discrete lateral and torsional restraints. The proposal presented hereafter is a continuation of authors' investigations presented in $[2,3]$. In this paper a more consistent Ayrton-Perry approach is developed than that presented in [3]. It uses the in-plane plastic collapse load multiplier of perfect beam-columns (based on the proposal given in [4]) that is combined with the outof-plane elastic load multiplier according to the solution presented in [14] for the evaluation of the beam-column slenderness ratio under different combination of load effects.

Beam-columns of class 1 and 2 bisymmetric I-sections are considered hereafter. An example of an $\mathrm{H}$-section beam-column under a single curvature and a double curvature (symmetric and antisymmetric moment loading conditions, respectively) is considered in this paper. The results are compared with those yielding from the Eurocode's Method 1 interaction equations and from the formulation presented in [12].

\section{BASIC CONCEPT OF THE PROPOSED AYRTON-PERRY FORMULATION}

The basic assumption of the proposed concept is to maintain the definition for the slenderness ratio used for elemental cases of the beam LTB (lateral-torsional buckling) resistance and the columns FB or TB buckling resistance (flexural F or 
torsional T) in terms of both the meaning of variables and the way of inclusion of the effect of imperfections. As a results, the proposed generalized Ayrton-Perry formulation coincides with that used in [1] for the buckling resistance evaluation of I or H-section columns and beams.

The basic concept of proposed approach is illustrated in Figure 1 in which the point $\mathrm{A}_{\mathrm{Ed}}$ represents the dimensionless load effects due to the applied design loads while $A_{c r}$ and $A_{i p, R k}$ represent the critical state with regard to elastic flexuraltorsional buckling and the in-plane plastic collapse state without any effect of imperfections included. Two generalized load multipliers associated with two mentioned above characteristic member states under the fixed proportion between the load effects need to be evaluated. They are defined as follows:

1. The critical load multiplier $\alpha_{c r}$ has an explicit graphical interpretation as it is illustrated in Figure 1:

$$
\alpha_{c r}=\frac{\overrightarrow{\mathrm{OA}_{\mathrm{cr}}}}{\overrightarrow{\mathrm{OA}_{\mathrm{Ed}}}}
$$

2. The collapse load multiplier $\alpha_{i p, R k}$ has also an explicit graphical interpretation and might be expressed as:

$$
\alpha_{i p, R k}=\frac{\overrightarrow{\mathrm{OA}_{\mathrm{ip}, \mathrm{Rk}}}}{\overrightarrow{\mathrm{OA}_{\mathrm{Ed}}}}
$$

The load multiplier associated with the characteristic buckling resistance of imperfect beam-column elements $\alpha_{b, R k}$ can be expressed through the reduction factor $\chi_{k}$ as follows:

$$
\alpha_{b, R k}=\chi_{k} \alpha_{i p, R k}
$$

in which the characteristic value of the reduction factor $\chi_{k}$ is defined in the same way as given for the elementary cases of the buckling resistance of beams and columns in [11].

The Ayrton-Perry formulation for the buckling reduction factor $\chi_{k}$ of the characteristic member resistance leads to the following equation [11]:

$$
\left(1-\chi_{k} \bar{\lambda}_{k}^{2}\right)\left(1-\chi_{k}\right)=\eta \chi_{k}, \quad \eta=\alpha_{b}\left(\bar{\lambda}_{k}-0.2\right)
$$

in which the imperfection factor for the flexural-torsional buckling $\alpha_{b}$ is to be interpolated between that of beam buckling $\alpha_{L T}$ and that of column buckling $\alpha$ (see section 5) while the relative slenderness ratio is calculated as: 


$$
\bar{\lambda}_{k}=\sqrt{\frac{\alpha_{i p, R k}}{\alpha_{c r}}}
$$

In Figure 1, the load multiplier $\alpha_{b, R k}$ is graphically associated with the point $A_{b, R k}$, and it might be expressed as:

$$
\alpha_{b, R k}=\frac{\overrightarrow{\mathrm{OA}_{\mathrm{b}, \mathrm{Rk}}}}{\overrightarrow{\mathrm{OA}_{\mathrm{Ed}}}}
$$

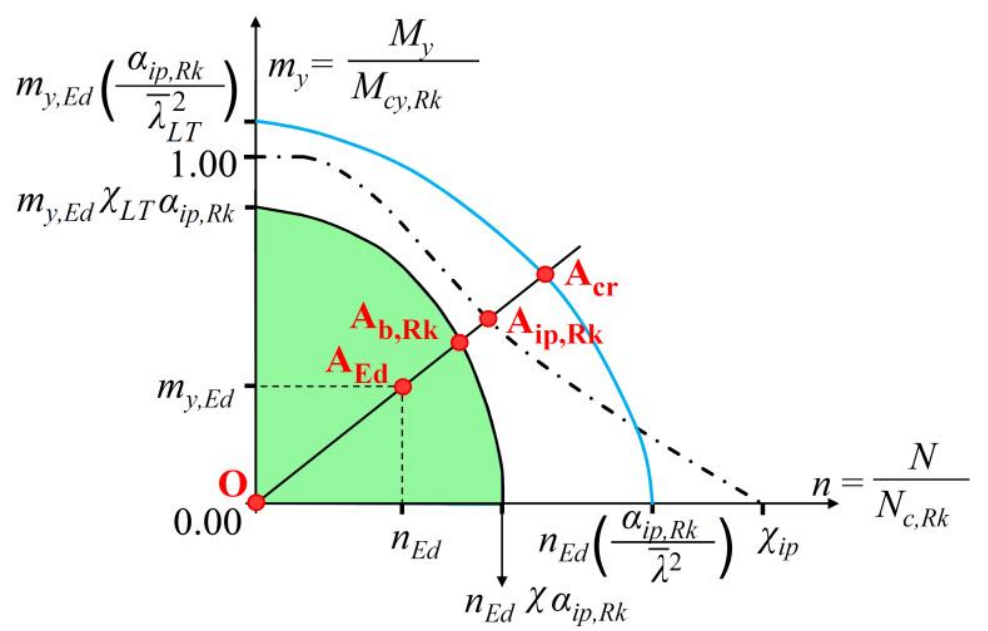

Fig. 1. Graphical interpretation of the proposed generalized Ayrton-Perry formulation, using the imperfection factor $\alpha$ corresponding to $\chi=\min \left(\chi_{y}, \chi_{z}, \chi_{T}\right)$

Points $A_{c r}, A_{i p, R k}$ and $A_{b, R k}$ evaluated for different proportions between load effects constitute respectively: the flexural-torsional critical load interaction curve, the in-plane collapse load interaction curve and finally - the flexural-torsional buckling resistance interaction curve. It is important to note that discrete lateral and torsional in-span restraints do not affect the beam-column in-plane behaviour. As a result, the position of in-plane collapse load interaction curve becomes unaffected while the shape of flexural-torsional critical load interaction curve is significantly affected. It becomes uplifted with regard to greater values of the critical load multiplier $\alpha_{c r}$ in the domain of greater bending moments in relation to the compressive axial force. Contrarily, there is a greater chance for the critical force about $y-y$ axis to drop down below the critical force about $z-z$ axis that usually governs the critical state of longer unrestrained columns. The method proposed herein widens therefore the scope of application of the generalized Ayrton-Perry formulation presented in [12]. 


\section{IN-PLANE COLLAPSE LOAD MULTIPLIER}

Since the effect of imperfections is introduced in the Ayrton-Perry formulation through the introduction of the imperfection parameter, the collapse load multiplier involved in the evaluation of slenderness ratio is to be calculated for the perfect structure but with a proper account for the second-order in-plane $P-\delta$ effect. This means that an advanced type of inelastic analysis is to be used in the evaluation of the said multiplier. This may be done using the finite element equilibrium path analysis [7] or any other analytical formulation that is able to reproduce the numerical results with an accuracy being acceptable from the engineering point of view. The latter option is postulated in the present study. Since the analytical formulation used herein is the modified one of that presented elsewhere [4], only the final form applied to perfect beam-columns is presented hereafter. Let us use dimensionless variables of the following format:

$$
n_{E d}=\frac{N_{E d}}{N_{c, R k}}, \quad m_{y, E d}=\frac{M_{y, E d}}{M_{c y, R k}}, \quad \alpha_{n}=\frac{n_{E d}}{m_{y, E d}}, \quad \alpha_{m}=\frac{m_{y, E d}}{n_{E d}}
$$

where $N_{c, R k}$ is the axial force cross-section resistance and $M_{c y, R k}$ - the bending moment cross-section resistance about $y$ - $y$ axis.

The in-plane ultimate limit state of perfect members is section class dependent. For class 3 and 4 I-sections, the section resistance is described by the well-known linear equation. In case of class 1 and 2 I-section members, the section plastic resistance curve is nonlinear and convex. For bisymmetric I-sections and a certain value of $\alpha_{n}$ ratio, the in-plane ultimate limit state of perfect beam-columns of class 1 or 2 sections is described by equations based on the plastic hinge method. For Eurocode's bi-linear simplification of the $n_{E d}-m_{y, E d}$ curve, the following equations hold for the element resistance under moment gradient:

a) for $0 \leq \alpha_{n}<\frac{a}{2}$

$$
\begin{aligned}
& 0.5 \alpha_{i p, R k} m_{y, E d}\left[1+\psi_{y}+\left(1-\psi_{y}\right)\left(1-\xi_{\max }\right)\right]+ \\
& \alpha_{i p, R k} n_{E d}\left[\beta_{\delta} \eta_{E d, y} \bar{w}_{1}\left(\xi_{\max }\right)+\beta_{\delta 2} \eta_{E d, y, 2} \bar{w}_{2}\left(\xi_{\max }\right)\right]=1
\end{aligned}
$$

b) for $\frac{a}{2} \leq \alpha_{n}$

$$
\begin{aligned}
& 0.5 \alpha_{i p, R k} m_{y, E d}\left[1+\psi_{y}+\left(1-\psi_{y}\right)\left(1-\xi_{\max }\right)\right]+ \\
& \alpha_{i p, R k} n_{E d}\left[\beta_{\delta} \eta_{E d, y} \bar{w}_{1}\left(\xi_{\max }\right)+\beta_{\delta 2} \eta_{E d, y, 2} \bar{w}_{2}\left(\xi_{\max }\right)\right]=\frac{1-\alpha_{i p, R k} n_{E d}}{1-0.5 a}
\end{aligned}
$$


where $\beta_{\delta}$ and $\beta_{\delta 2}$ are the amplification factors corresponding to the two lowest flexural in-plane buckling modes:

$$
\beta_{\delta}=\frac{1}{1-\bar{\lambda}_{y}^{2} \alpha_{i p, R k} n_{E d}}, \quad \beta_{\delta 2}=\frac{1}{1-0.25 \bar{\lambda}_{y}^{2} \alpha_{i p, R k} n_{E d}}
$$

$a$ is the section parameter according to [1], $\xi_{\max }$ - the dimensionless coordinate along $x$-axis (assumption: $\xi=2 x / L$, where $L$ is a length of the element) that corresponds to the section of maximum section resistance utilization ratio under bending and compression (where multiplier $\alpha_{i p, R k}$ has minimum positive value for considered dimensionless variables $n_{E d}$ and $\left.m_{y, E d}\right), \psi_{y}$ - the support moments ratio ( $\psi_{y}=M_{y, E d, \text { supp,min }} / M_{y, E d, \text { supp,max }}$, where $M_{y, E d, \text { supp,max }}$ and $M_{y, E d, \text { supp,min }}$ are maximum and minimum support moment, respectively), $\bar{\lambda}_{y}$ - the flexural slenderness ratio about $y-y$ axis corresponding to the lowest half-sine bifurcation mode, $\bar{w}_{1}(\xi)$, $\bar{w}_{2}(\xi)$ - the shape functions dependent upon the dimensionless coordinate along $x$-axis corresponding to a symmetric single curvature and an antisymmetric double curvature, respectively, $\eta_{E d, y}, \eta_{E d, y, 2}$ - the dimensionless first order displacement amplitude corresponding, respectively, to the equal end moments of the opposite directions (single curvature case) and to the equal end moments of the same direction (double curvature case):

$$
\begin{aligned}
& \eta_{E d, y}=\alpha_{i p, R k} m_{y, E d} \frac{N_{c, R k} L^{2}}{16 E I_{y}}\left(1+\psi_{y}\right), \\
& \eta_{E d, y, 2}=\alpha_{i p, R k} m_{y, E d} \frac{N_{c, R k} L^{2}}{128 E I_{y}}\left(1-\psi_{y}\right)
\end{aligned}
$$

in which the other notations are according to [1].

The characteristic buckling resistance may be evaluated using two possible approaches:

- Approach 1: Combining the linear stability solution described by equation (4.1) from the following section and the solution of characteristic member inplane resistance described by equations (3.2) and (3.3), with the assumption of neglecting the effect of in-plane buckling (i.e. $\beta_{\delta}=1.0, \beta_{\delta 2}=1.0$ ),

- Approach 2: Combining the linear stability solution described by equation (4.1) from the following section but with the assumption of neglecting the effect of in-plane buckling (i.e. $N_{E d} / N_{c r, y} \equiv 0$ ), and the solution of 
characteristic in-plane buckling resistance described by equations (3.2) and (3.3).

It has to be noted that both approaches, Approach 1 and Approach 2, utilize the member in-plane resistance that differs from that of the cross section in-plane resistance. In this context, the in-plane buckling reduction factor $\chi_{i p}$ used in Figure 1 is approach dependent according the following notation:

- for Approach 1:

$$
\chi_{i p}=1, \quad \bar{\lambda}=\max \left(\bar{\lambda}_{y}, \bar{\lambda}_{z}, \bar{\lambda}_{T}\right)
$$

- for Approach 2:

$$
\chi_{i p}=\min \left(1,1 / \bar{\lambda}_{i p}^{2}\right), \quad \bar{\lambda}=\max \left(\bar{\lambda}_{z}, \bar{\lambda}_{T}\right)
$$

where $\bar{\lambda}_{y}, \bar{\lambda}_{z}, \bar{\lambda}_{T}$ are the column slenderness ratios corresponding to flexural buckling about $y-y$ and $z-z$ axes, and to torsional buckling about $x$-x axis, $\bar{\lambda}_{i p}$ is the in-plane relative slenderness ratio equal to $0.5 \bar{\lambda}_{y}$ in case of anti-symmetric transverse loading components and equal to $\bar{\lambda}_{y}$ in the other cases of loading components.

The multiplier $\alpha_{i p, R k}$ for the in-plane resistance is therefore also the approach dependent. In Approach 1, the said multiplier is calculated from the equations (3.2) and (3.3) but neglecting the effect of in-plane buckling (i.e. $\beta_{\delta}=1.0$, $\beta_{\delta 2}=1.0$ ). Such an analysis is denoted hereafter by MNA+ since the classical analysis denoted by MNA is extended in order to calculate the bending moments as a sum of the first order moment stress resultants and additional moments resulting from the axial force being multiplied by the first order deflections $\delta_{0}=w_{0, E d} \bar{w}_{1}(\xi)$ and $\delta_{02}=w_{0, E d, 2} \bar{w}_{2}(\xi)$. In Approach 2 the multiplier $\alpha_{i p, R k}$ is calculated directly from the equations (3.2) and (3.3) with use of greater than unity amplification factors according to equations (3.4). It is important to note that for $m_{y, E d}=0$ the value of multiplier $\alpha_{i p, R k}$ is to be calculated for an infinitesimally small value of the $m_{y, E d}$ (for example for $m_{y, E d}=10^{-6}$ ). Such an analysis is denoted hereafter by GMNA+ in accordance to the definition presented in [6].

In the detailed analysis presented hereafter, the simply supported beam-column of HEB 300 section of the steel grade S 235 is taken into consideration. According to Eurocode 3 [1] the cross section is class 1 in pure compression (the most unfavourable load situation) and can be treated as a class 1 cross section for all others combinations of the bending moment and axial force. The section resistances for this section are as follows $N_{c, R k}=A \cdot f_{y}=149.1 \cdot 23.5=3504 \mathrm{kN}$, $M_{c y, R k}=W_{p l, y} \cdot f_{y}=1869 \cdot 23.5=439.2 \mathrm{kNm}$ and the section resistance parameter 
$a=0.235$ for the combination of bending moment and axial force. Three values of the slenderness ratio $\bar{\lambda}_{y}$ corresponding to compression are accounted for, namely equal to $0.5,1.0$ and 1.5 (the element length corresponds to $6101 \mathrm{~mm}$, $12202 \mathrm{~mm}$ and $18303 \mathrm{~mm}$, respectively). Using the trigonometric sin-functions to represent the shape functions given by $\bar{w}_{1}(\xi)=\sin (0.5 \pi \xi)$ and $\bar{w}_{2}(\xi)=\sin (\pi \xi)$, calculations were performed according to equations (3.2) and (3.3) for 9 discrete values of $\alpha_{n}$ and $\alpha_{m}$ take $0.00,0.25,0.50,0.75,1.00$ and additionally $\alpha_{n}=0.5 a$, representing the certain proportion between the axial force and the bending moment. The results are presented in Figure 2 by solid (Approach 1) and dashed (Approach 2) lines that link the discrete points obtained from calculations for certain proportion between the axial force and the bending moment. For comparison, the Eurocode's interaction curve for the cross-section resistance [1] (the slenderness ratio equal or less than 0.2 ) is also given by dotted line.

The results show that for the uniform moment and compression the interaction curves representing the formation of the plastic hinge in the middle length section are below those of the cross-section resistance. The in-plane plastic limit curves for Approach 1 are above those obtained from Approach 2, especially for $m_{y, E d} \rightarrow 0$. In contrast, the in-plane inelastic stability limit curves obtained from Approach 2 are placed lower than those from MNA+. It is important to note that for $m_{y, E d}=0$ the value of multiplier $\alpha_{i p, R k}$ obtained for Approach 1 from MNA+ does not refer to the dimensionless in-plane stability criterion $\alpha_{i p, R k} n_{E d}=\min \left(1,1 / \bar{\lambda}_{i p}^{2}\right)$ obtained from GMNA+ in which an infinitesimally small value of $m_{y, E d}$ is used in order to activate the buckling path. In Approach 1 the results obtained for $m_{y, E d}=0$ refer to the yielding criterion $\alpha_{i p, R k} n_{E d}=1.0$.

In case of antisymmetric moment diagram, the interaction curves consist of two branches, one representing the formation of the plastic hinge at the distance ranging from zero to $L / 4$ from the end point, and the second one representing the formation of the plastic hinge at the end section (coinciding with the section resistance interaction curve). The results are however very close to each other, therefore also to those representing the section in-plane resistance under the combination of bending moment and axial force. 
A CONSISTENT AYRTON-PERRY APPROACH FOR THE FLEXURAL-TORSIONAL 97 BUCKLING RESISTANCE EVALUATION OF STEEL I-SECTION MEMBERS

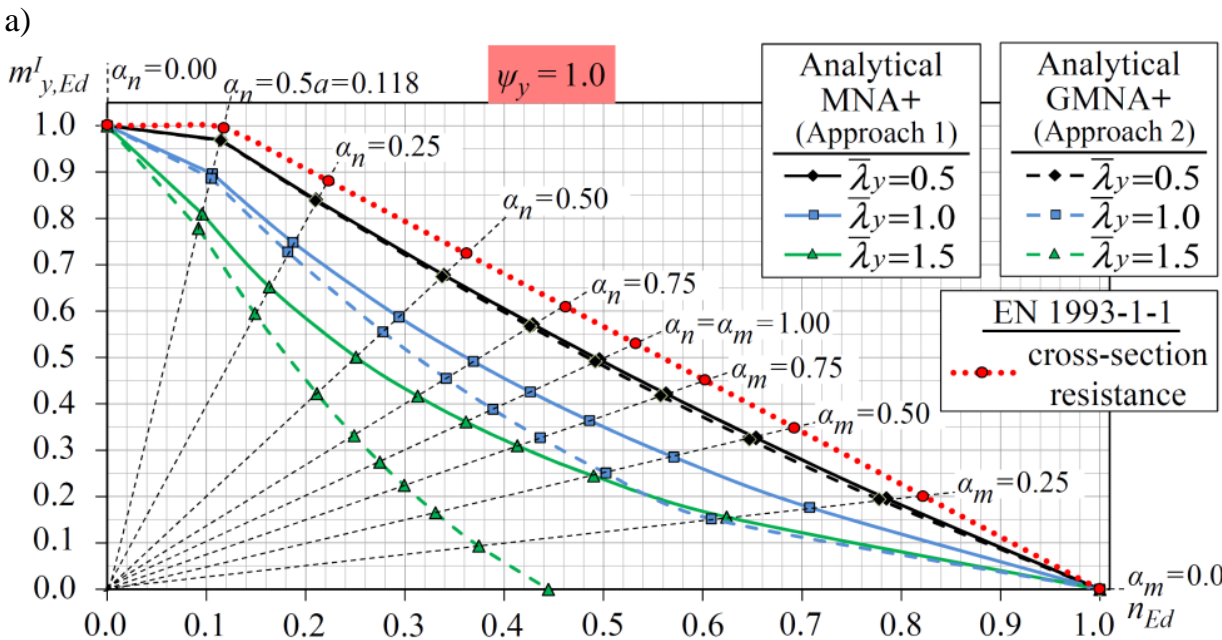

b)

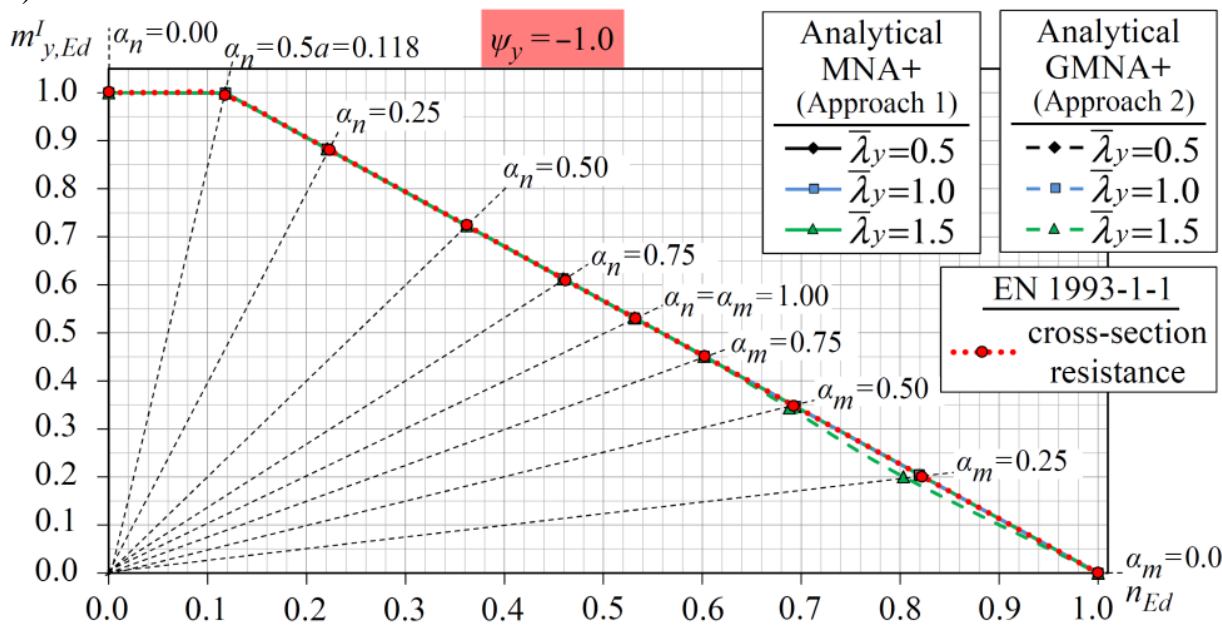

Fig. 2. Collapse load interaction curve in dimensionless coordinates $n_{E d}$ and $m_{y, E d}$, a) symmetric bending $\left(\psi_{y}=1\right)$, b) antisymmetric bending $\left(\psi_{y}=-1\right)$ 


\section{CRITICAL LOAD MULTIPLIER}

The critical load multiplier $\alpha_{c r}$ is calculated in different way for the inclusion in Approach 1 and Approach 2.

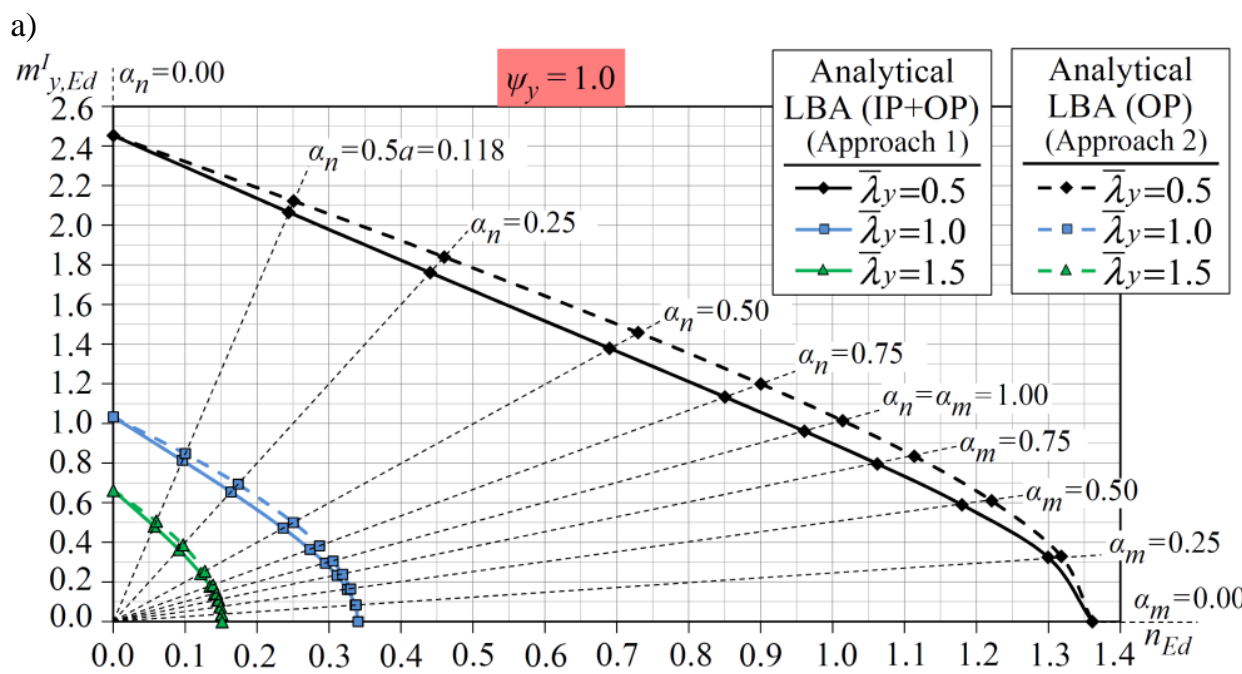

b)

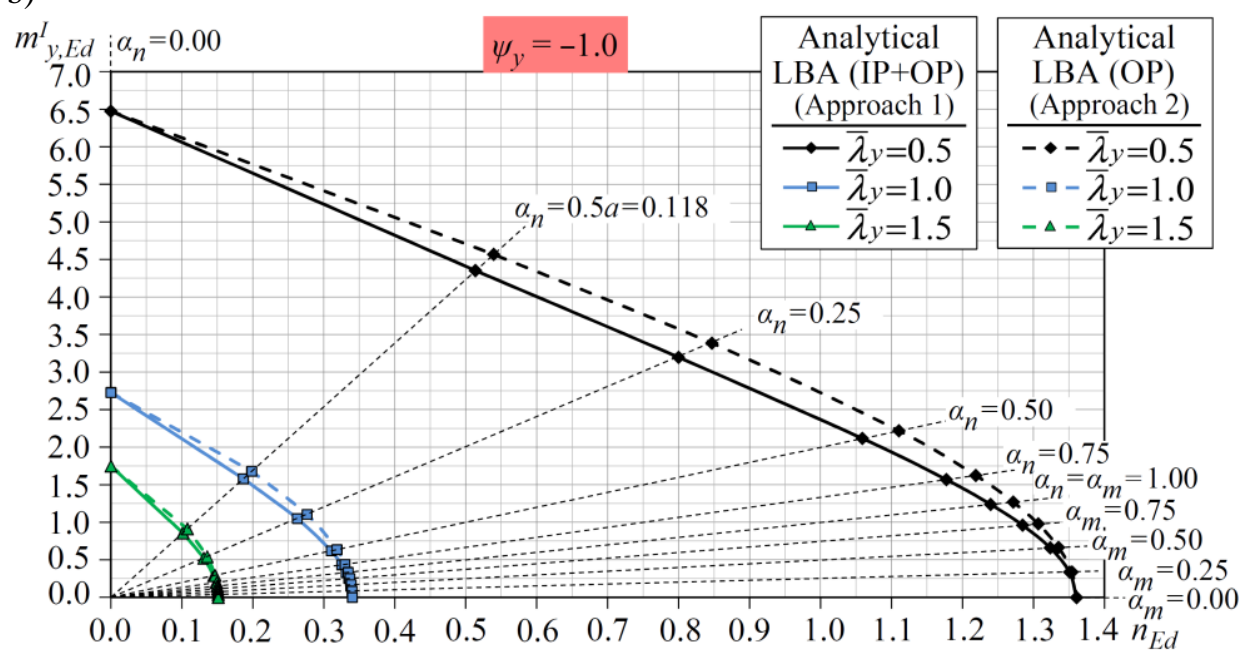

Fig. 3. Critical load interaction curve in dimensionless coordinates $n_{E d}$ and $m_{y, E d}$, a) symmetric bending $\left(\psi_{y}=1\right)$, b) antisymmetric bending $\left(\psi_{y}=-1\right)$ 
In Approach 1 it is calculated with use of the solution obtained in [14] according to linear buckling analysis (LBA) and neglecting the beneficial effect of prebuckling displacement on the elastic flexural-torsional instability:

$$
\left(\alpha_{c r} m_{y, E d} \bar{\lambda}_{L T}^{2}\right)^{2}=\left(1-\alpha_{c r} n_{E d} \bar{\lambda}_{y}^{2}\right)\left(1-\alpha_{c r} n_{E d} \bar{\lambda}_{z}^{2}\right)\left(1-\alpha_{c r} n_{E d} \bar{\lambda}_{T}^{2}\right)
$$

where $\bar{\lambda}_{L T}$ is the beam slenderness ratio corresponding to lateral-torsional buckling (LTB).

Since in Approach 1, both in-plane and out-of-plane buckling effects are considered, the solution is denoted hereafter by LBA IP+OP.

In Approach 2, the critical load multiplier $\alpha_{c r}$ is also calculated from equation (4.1) but neglecting the effect of in-plane buckling (i.e. $N_{E d} / N_{c r, y} \equiv 0$ ). Since in this case only the out-of-plane buckling effects are considered, the solution is denoted by LBA OP.

The calculation were performed to evaluate the critical load interaction curves for the same cases as presented in Figure 2 for the in-plane collapse load interaction curves. The results are presented in Figure 3. The critical moment for the lateraltorsional slenderness ratio is for the moment gradient ratio $\psi_{y}$ calculated according to [5]:

$$
\frac{1}{M_{c r}}=\frac{\bar{\lambda}_{z} \bar{\lambda}_{T}}{i_{C} N_{c, R k}}\left[\left(\frac{1+\psi_{y}}{2}\right) \frac{1}{C_{1, s}}+\frac{1}{2}\left(\frac{1-\psi_{y}}{2}\right)^{3} \frac{1}{C_{1, a}}\right]
$$

where $C_{1, s}=1.00, C_{1, a}=1.32$ and the other notation is according to the ECCS Manual [10].

\section{BUCKLING LOAD MULTIPLIER}

The solution of equation (2.4) for the flexural-torsional buckling resistance of beam-columns coincides with that for the columns and beams given in $[1,10]$. The buckling characteristic resistance load multiplier is then calculated using the multiplicative form of (2.3). The flexural-torsional load multiplier for the buckling design resistance is evaluated according to [11].

The imperfection factor is suggested to be calculated from the following interpolation formula:

$$
\alpha_{b}=\frac{\alpha_{L T}}{1+\alpha_{n}}+\frac{\alpha}{1+\alpha_{m}}
$$


where $\alpha$ stands for $\alpha_{y}$ when the flexural buckling reduction factor $\chi_{y}$ has the minimum value or $\alpha_{z}$ when the flexural buckling reduction factor $\chi_{z}$ or the torsional buckling reduction factor $\chi_{T}$ is of the minimum value; $\alpha_{n}$ and $\alpha_{m}$ are the factors describing the proportion between the dimensionless stress resultants.

\section{VERIFICATION OF THE PROPOSED FORMULATION}

The verification is presented by comparison the buckling resistance curves from the proposed method and those predicted with use of the Eurocode's interaction equations and the Ayrton-Perry formulation proposed in [12]. It has to be noted that the Ayrton-Perry formulation presented in [12] is based on the improved lateral-torsional buckling curves developed in [13] for hot-rolled I and $\mathrm{H}$ sections (improved in relation to the original Eurocode's recommendations). The section geometry and lengths are indicated in chapters 4 and 5 for the calculation of the beam-column in-plane behaviour and the elastic stability behaviour, respectively. Table 1 presents the summary of element slenderness ratios for three considered lengths and the buckling reduction factors for boundary cases of axial compression alone and bending alone.

Table 1. Summary of element slenderness ratios and reduction factors

\begin{tabular}{|c|c|c|c|c|c|c|c|}
\hline $\bar{\lambda}_{y}$ & $\bar{\lambda}_{z}$ & $\bar{\lambda}_{T}$ & $\begin{array}{c}\bar{\lambda}_{L T} \\
\left(\psi_{y}=1\right)\end{array}$ & $\begin{array}{c}\bar{\lambda}_{L T} \\
\left(\psi_{y}=-\right. \\
1)\end{array}$ & $\chi=\chi_{z}$ & $\begin{array}{c}\chi_{L T} \\
\left(\psi_{y}=1\right)\end{array}$ & $\begin{array}{c}\chi_{L T} \\
\left(\psi_{y}=-\right. \\
1)\end{array}$ \\
\hline 0.5 & 0.857 & 0.571 & 0.639 & 0.393 & 0.626 & 0.875 & 0.955 \\
\hline 1.0 & 1.714 & 0.677 & 0.984 & 0.605 & 0.254 & 0.677 & 0.888 \\
\hline 1.5 & 2.572 & 0.704 & 1.228 & 0.756 & 0.126 & 0.512 & 0.820 \\
\hline
\end{tabular}

Since the reduction factor $\chi_{z}$ governs the design for axial compression, the flexural-torsional buckling $\alpha_{b}$ is calculated according to equation (5.1) using $\alpha_{L T}=0.21$ and $\alpha=\alpha_{z}=0.49$.

Figure 4 shows the out-of-plane buckling results obtained for the slenderness ratio $\bar{\lambda}_{y}$ equal to $0.5,1.0$ and 1.5 where for each discrete point of the load factor the slenderness ratio is calculated according to (2.5) using results presented in Figures 3 and 4, and the reduction factor with use of the imperfection factor according to (5.1). The results from the formulation developed in this paper are represented by solid (Approach 1) and dashed (Approach 2) lines and compared with those obtained with use of Eurocode's Method 1 interaction equations. The Eurocode's lateral-torsional buckling reduction factors are calculated in two distinctive ways, namely using the LTB general procedure according to the clause 6.3.2.2 (denoted 
A CONSISTENT AYRTON-PERRY APPROACH FOR THE FLEXURAL-TORSIONAL 101 BUCKLING RESISTANCE EVALUATION OF STEEL I-SECTION MEMBERS

by dotted lines), and using the LTB alternative procedure for rolled or equivalent welded sections according to the clause 6.3.2.3 (denoted by dash-dotted lines).

a)

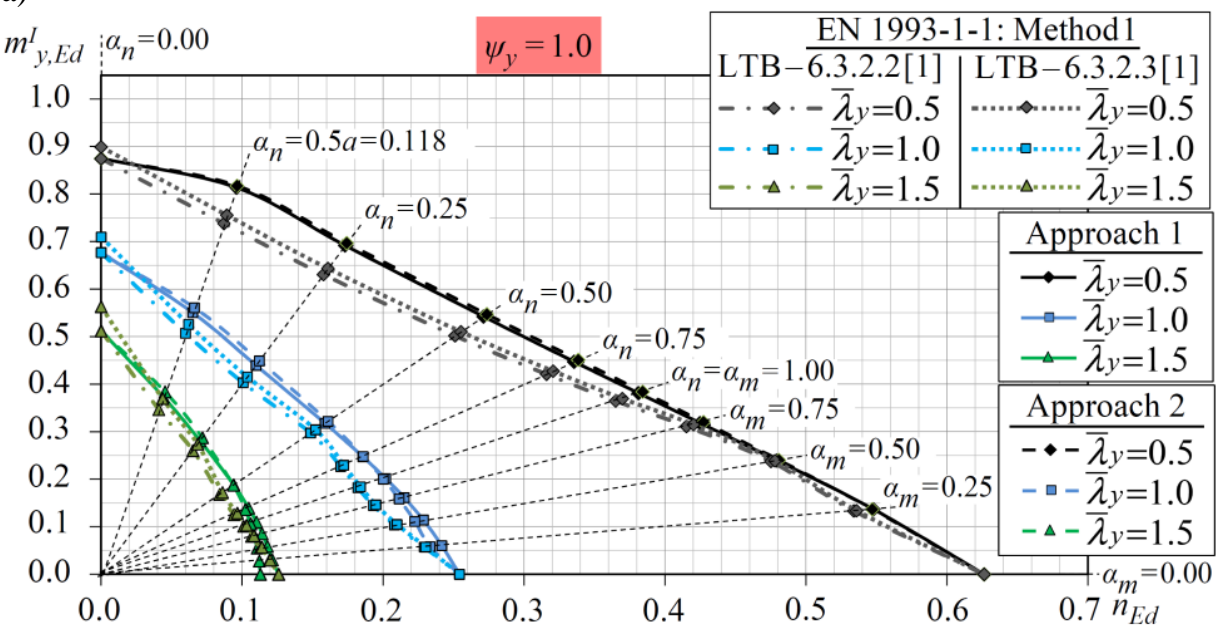

b)

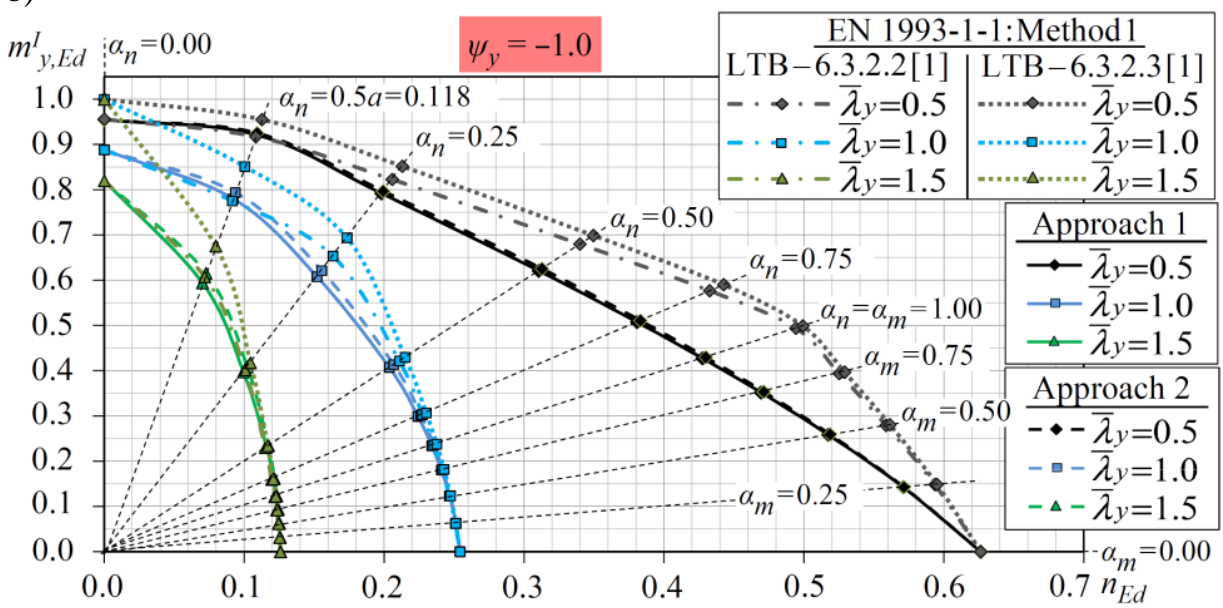

Fig. 4. Out-of-plane buckling resistance curve in dimensionless coordinates $n_{E d}$ and $m_{y, E d}$, a) symmetric bending $\left(\psi_{y}=1\right)$, b) antisymmetric bending $\left(\psi_{y}=-1\right)$

Figure 5 presents the verification of developed formulation using the AyrtonPerry formulation published recently in [12]. The results from the formulation developed in this paper are the same as in Figure 4 while those obtained with use of the Ayrton-Perry formulation presented in [12] are indicated by dotted lines. 
a)

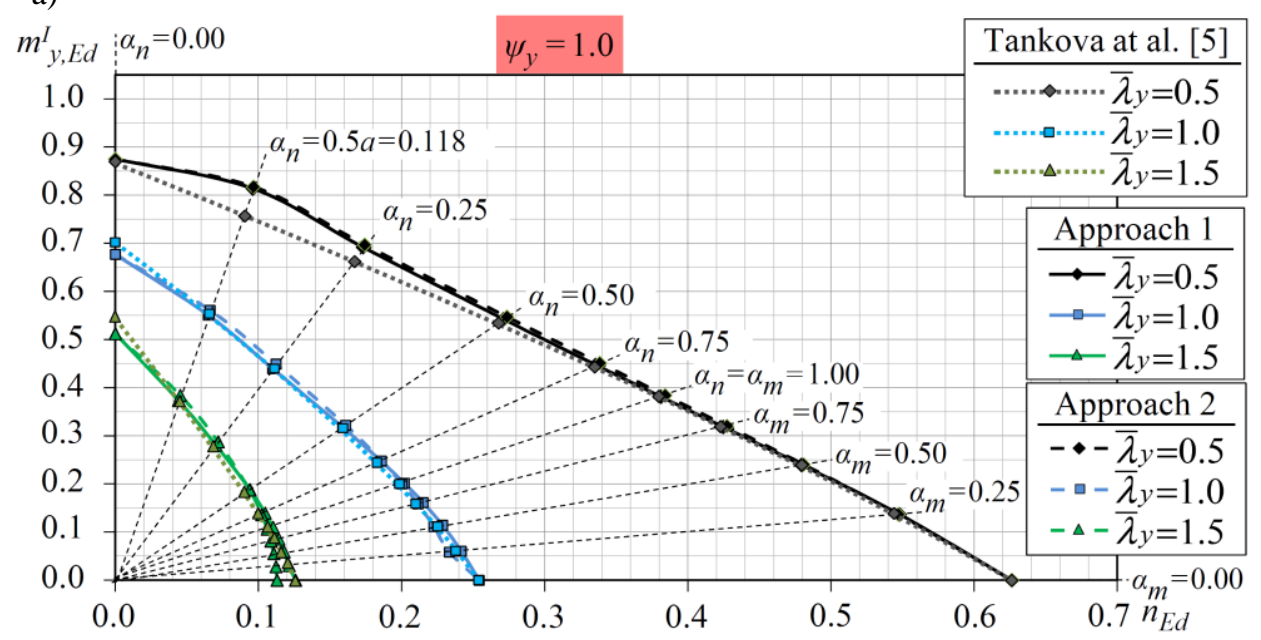

b)

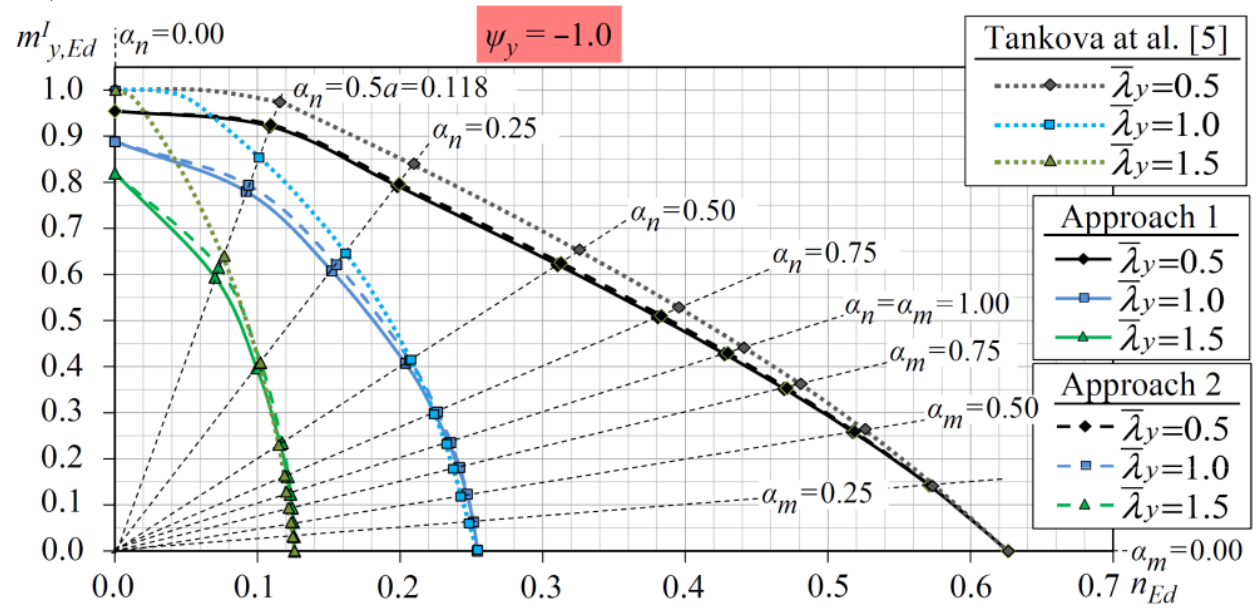

Fig. 5. Out-of-plane buckling resistance curve in dimensionless coordinates $n_{E d}$ and $m_{y, E d}$, a) symmetric bending $\left(\psi_{y}=1\right)$, b) antisymmetric bending $\left(\psi_{y}=-1\right)$

The results obtained using both analytical approaches are close to each other and for the uniform moment and compression are placed above those obtained from Eurocode's Method 1. In the same case of loading conditions there is a very good consistency between the analytical results obtained according to both Approach 1 and Approach 2, and Ayrton-Perry formulation presented in [12]. In case of antisymmetric moment diagram, the analytical interaction curves for both 
A CONSISTENT AYRTON-PERRY APPROACH FOR THE FLEXURAL-TORSIONAL 103 BUCKLING RESISTANCE EVALUATION OF STEEL I-SECTION MEMBERS

approaches are below those obtained in [12] but they are similar or below those obtained from Eurocode's Method 1 interaction equations with LTB calculated according to clause 6.3.2.2 of [1]. For small values of $n_{E d}$, resistance curves according to [12] are closer to Eurocode's interaction curves with LTB calculated according to clause 6.3.2.3 of [1] than those with LTB calculated according to clause 6.3.2.2 of [1].

\section{CONCLUDING REMARKS}

In this paper, the application of consistent Ayrton-Perry analytical formulation is presented for steel I-section members subjected to compression and monoaxial bending about the major axis. Advantages of the proposed formulation are as follows:

1. Easy graphical interpretation.

2. Only one design condition for checking the beam-column resistance instead of two buckling resistance conditions and one section resistance condition postulated in Eurocode 3 [1].

3. Elimination of the necessity of equivalent uniform moment factors to be involved in interaction design criteria.

The proposed Ayrton-Perry design strategy is similar to that utilized in the steel Eurocode 3 [1] for design of beams and columns but not used so far for the beamcolumn design. Two approaches are possible for the calculation of load multipliers $\alpha_{c r}$ and $\alpha_{i p, R k}$. In Approach 1, the factor $\alpha_{c r}$ does not take the effect of in-plane buckling into account since this effect is considered in the evaluation of $\alpha_{i p, R k}$. Contrarily, in Approach 2 the factor $\alpha_{c r}$ takes the effect of in-plane buckling into consideration since it is neglected in the evaluation of $\alpha_{i p, R k}$.

Investigations presented in this paper are dealt with bisymmetric I-sections of class 1 and 2. The illustrative example of HEB 300 section beam-column under symmetric and antisymmetric moment loading conditions is considered for three values of the slenderness ratio corresponding to compression, namely equal to $0.5,1.0$ and 1.5. The results from the design criterion developed in this paper are compared with those of Method 1 of Eurocode 3 [1] and the alternative AyrtonPerry formulation that has been recently published [12]. Approaches 1 and 2 lead to the results being close to each other and have quite good consistency with the results obtained from Eurocode's Method 1 interaction equations [1] and from the formulation presented in [12].

The developed modelling technique is of a general nature and may be easily extended for bisymmetric I-sections of class 3 and 4, and for monosymmetric Isections. In the former case, the linear section resistance interaction curve has to be adopted while in the latter - adopting a different section resistance curve for class 1 and 2 sections, and also different elastic FTB member resistance curve. 


\section{REFERENCES}

1. Eurocode 3. EN 1993-1-1: Design of Steel Structures, Pat 1-1: General rules and rules for buildings, CEN 2005.

2. Gizejowski M., Stachura Z.: Buckling strength of a steel multi-storey framework according to Eurocode's general method. In: Recent Progress in Steel and Composite Structures (eds. M. Gizejowski, A. Kozlowski, J. Marcinowski \& J. Ziolko), London. Taylor \& Francis Group 2016, 154-155, e-book on CD, 381-391.

3. Gizejowski M., Stachura Z.: Generalized Ayrton-Perry approach for the evaluation of beam-column resistance. In: Insights and Innovations in Structural Engineering, Mechanics and Computation (ed. A. Zingoni), London, Taylor \& Francis Group, 2016, 253-254, e-book on CD, 713-719.

4. Gizejowski M.A., Stachura Z., Gajewski M.D., Szczerba R.B.: A new method of buckling resistance evaluation of laterally restrained beam-columns. In: Recent Progress in Steel and Composite Structures (eds. M.A. Gizejowski, A. Kozlowski, J. Marcinowski \& J. Ziolko), London, Taylor \& Francis Group 2016, 102-103, e-book on CD, 197-205.

5. Gizejowski M.A., Stachura Z., Uziak J.: Elastic flexural-torsional buckling of beams and beam-columns as a basis for stability design of members with discrete rigid restraints. In: Insights and Innovations in Structural Engineering, Mechanics and Computation (ed. A. Zingoni), London, Taylor \& Francis Group 2016, 261-262, e-book on CD, 738-744.

6. Gizejowski M.A., Szczerba R.B., Gajewski M.D., Stachura Z.: Beam-column in-plane resistance based on the concept of equivalent geometric imperfections. Archives of Civil Engineering, 62, 4 (2016) 35-71.

7. Gizejowski M.A., Szczerba R.B., Gajewski M.D., Stachura Z.: Buckling resistance assessment of steel I-section beam-columns not susceptible to LTbuckling. Archives of Civil and Mechanical Engineering, 17, 2 (2017) 205221.

8. Papp F.: Buckling assessment of steel members through overall imperfection method. Engineering Structures 106 (2016) 124-136.

9. Simoes da Silva L., Marques L., Rebelo C.: Numerical validation of the general method in EC3-1-1 for prismatic members. Journal of Constructional Steel Research, 66 (2010) 575-590.

10. Simoes da Silva L., Simoes R., Gervasio H.: Design of Steel Structures, $2^{\text {nd }}$ Edition, Eurocode 3: Design of Steel Structures, Pat 1-1: General rules and rules for buildings, ECCS, Ernst \& Sohn 2016.

11. Stachura Z., Gizejowski M.: Partial factors in modelling of steel structures reliability according to Eurocodes. Civil and Environmental Engineering 
A CONSISTENT AYRTON-PERRY APPROACH FOR THE FLEXURAL-TORSIONAL 105 BUCKLING RESISTANCE EVALUATION OF STEEL I-SECTION MEMBERS

Reports, Zielona Góra, University of Zielona Góra Press, 16, 1 (2015) $195-$ 207.

12. Tankova T., Marques L., Andrade A., Simoes da Silva L.: A consistent methodology for the out-of-plane buckling resistance of prismatic steel beamcolumns. Journal of Constructional Steel Research, 128 (2017) 839-852.

13. Taras A., Greiner R.: New design curves for lateral-torsional buckling Proposal based on a consistent derivation. Journal of Constructional Steel Research, 66, 5 (2010) 648-663.

14. Trahair N.S.: Flexural-Torsional Buckling of Structures. Boca Raton, CRC Press Inc. 1993.

\section{JEDNOLITE PODEJŚCIE AYRTON-PERRY'EGO W OCENIE NOŚNOŚCI STALOWYCH ELEMENTÓW DWUTEOWYCH PRZY WYBOCZENIU GIĘTNO-SKRĘTNYM}

\section{Streszczenie}

Niniejsza praca dotyczy stalowych elementów o przekrojach dwuteowych poddanych osiowemy ściakaniu i jednokierunkowemu zginaniu w płaszczyźnie większej bezwładności przekroju. W takim przypadku procedura projektowania elementów wg aktualnej wersji eurokodu stalowego bazuje na zestawie dwóch interakcyjnych formuł analitycznych, dotyczących nośności elementu oraz zależności interpolacyjnej na nośność przekroju. W odniesienu do eurokodowego sprawdzania nośności elementów z uwzględnieniem ich stateczności, współczynniki interakcyjne łączące wykorzystanie nośności przy wyboczeniu i zwichrzeniu mogą być wyznaczane wg Metody 1 lub Metody 2. W niniejszym artykule przedstawiono prostą, a jednocześnie spójną metodologię projektowania elementów jednocześnie zginanych i ściskanych, zgodną z podejściem Ayrton-Perry'ego, analogiczną do wykorzystywanej w eurokodzie stalowym do sprawdzania stateczności belek i słupów, ale do tej pory niewykorzystywanej do oceny stateczności elementów jednoczesnie zginanych i ściskanych. Wyniki otrzymane z proponowanego $\mathrm{w}$ niniejszej pracy podejścia analitycznego porównano $\mathrm{z}$ wynikami otrzymanymi $\mathrm{z}$ formul eurokodowych, $\mathrm{w}$ których współczynniki interakcyjne wyznaczono Metodą 1 oraz $\mathrm{z}$ wynikami otrzymanymi $\mathrm{z}$ alternatywnej propozycji analitycznej, bazującej na odmiennym w porównaniu do zaprezentowanego w niniejszym artykule uogólnieniu podejścia Ayrton-Perry'ego.

Słowa kluczowe: dwuteownik stalowy, zginanie i ściskanie, nośność na wyboczenie, wyboczenie giętno-skrętne, uogólnione sformuowanie AyrtonPerry, eurokodowa metodologia projektowania

Editor received the manuscript: 11.07.2016 